\title{
SENTENCING UNDER THE MODEL PENAL CODE
}

\author{
PaUl W. Tappan*
}

I

It is the purpose of this paper to analyze the forms of prison sentencing and their relationship to parole, with special reference to provisions in the Model Penal Code of the American Law Institute. Underlying the tentative Code drafts, there are, of course, certain conceptions concerning what are appropriate objectives of the penal law. Put summarily, the provisions relating to sentencing and treatment are predicated on the assumption that the law should endeavor to protect society as fully as may reasonably be possible, both by measures of general and individual prevention and by the rehabilitation of offenders. It is further conceived that penal and correctional provisions should be designed to safeguard offenders against excessive and arbitrary penalties.

Patently, however, the form and duration of treatment required by different offenders vary considerably with such factors as the age, personality, offense, and prior social and criminal history of the individual and with the sociocultural context. The significance of such influences must be taken into account, both in the provisions of law and in their implementation. It appears, therefore, that a model code should be so formulated as to harmonize somewhat disparate treatment objectives. ${ }^{1}$ It should be designed also to facilitate an effective performance by judges

* B.A. I934, Clark University; M.A. 1935, Ph.D. I940, University of Wisconsin; LL.B. 1943, New York University; J.Sc.D. I945, Columbia University. Member of the New York bar; Professor of Law and Sociology, New York University; Fulbright Lecturer, University of Melbourne, Australia, 1958; Associate Reporter, American Law Institute's Model Penal Code. Consultant, Commission on Organized Crime, American Bar Association, 1950-52; Member Advisory Committee of Experts on the Prevention of Crime and the Treatment of Offenders, United Nations, 1952. Author, Dezineuent Ginls IN Couitr (1947), Sociology of Inheritance (1948); Juvenile Delinquency (1949), The Hanitual Sex OfFender (1950); co-author [with Francis E. Merrill, H. Warren Dunham, and Arnold M. Rose], SoctuL Problems (1950). Editor, Contemporary Correction (1951). Contributor to criminological, legal, sociological, and psychiatric periodicals.

${ }^{1}$ Model Penal Code $\$$ r.02(2) (Tent. Draft No. 2, 1954) sets out "the general purposes of the provisions governing the sentencing and treatment of offenders" as follows:

"(a) To prevent the commission of offenses;

(b) to promote the correction and rehabilitation of offenders:

(c) to safeguard offenders against excessive, disproportionate or arbitrary punishment;

(d) to give fair warning of the nature of the sentences that may be imposed on conviction of an offense;

(e) to differentiate among offenders with a view to a just individualization in thcir treatment;

(f) to define, coordinate and harmonize the powers, duties, and functions of the courts and of administrative officers and agencies responsible for dealing with offenders;

(g) to advance the use of generally accepted scientific methods and knowledge in the sentencing and treatment of offenders;

(h) to integrate responsibility for the administration of the correctional system in a State Department of Correction [or other single department or agency]." 
and correctional authorities in adapting legal norms to individual offenders so as to achieve these goals.

In attempting to develop provisions well-designed to accomplish such objectives as these, serious difficulties inhere-in particular, the intrinsic limitations of the correctional tools at hand, the persisting inadequacy of our knowledge about the efficacy of the methods that are employed, and the conflict among reputable authorities on quite fundamental issues of means and ends. To achieve an effective balance of methods and goals has been a major objective of the Code Reporters during the past six years-an objective that, with the help of legal and correctional authorities, they will continue to seek to realize during the remaining years of the project.

Let us look briefly at the development and forms of sentencing that are employed in the United States and then at some of the central provisions of the Code.

\section{II}

Serious semantic difficulties are involved in the analysis of the problems of sentencing and parole. The nomenclature generally employed is quite misleading. There can be little doubt, indeed, that much of the confusion that may be found in the critical literature in this field stems, on the one hand, from the loose and conflicting terminology of sentencing and, on the other, from the peculiarities in the historical evolution of sentencing and parole practices.

The definite-sentence system was, in origin, a product of classical criminology, with its emphasis upon equality and certainty of punishment expressed in the establishment of prescribed sanctions for every crime according to its seriousness. Its primary aim was deterrence, and only incidentally did it purport to remedy the arbitrary abuses that had characterized the preclassical practice of wide judicial discretion. The classical policy of prescribed terms was adopted in the French Penal Code of I79I and soon spread in both civil and common-law countries. Only twenty years later, however, the excessive rigidity of the system had been recognized, and it was modified in the Code of r81o and by subsequent laws of I824 and $\mathrm{I} 832$, which permitted a measure of judicial discrimination in sentencing in accordance with mitigating or aggravating circumstances. During the same period, there also developed the marking and grading system-first in British penology and then in the reformatories in the United States-and the practice of allowing "good time" reduction of imprisonment-first in New York in $18 x_{7}$-both of which reduced the definiteness of correctional sentences.

A more significant change in the definite-sentence system, however, came with the development in the late nineteenth century of conditional-release measures, innovations that made obsolete the original and ostensible meaning of the definite sentence. Parole and the indeterminate sentence, while two quite distinct penological concepts, have become very closely interdependent in the course of their development. Parole was initially applied to young offenders under indeterminate sentences at the Elmira (New York) Reformatory in 1869 , but it was extended to adult 
prisoners in Ohio in $188_{4}$ and thence spread rapidly to other jurisdictions, where it was employed in connection with definite as well as indeterminate sentences. Indeed, in I900, although only eleven jurisdictions had enacted indeterminate-sentence laws, twenty had adopted parole. ${ }^{2}$ In the definite-sentence states, laws were drafted rendering prisoners eligible for conditional release upon the expiration of some part of their sentences. The effect of this was, in fact, to create another form of indeterminate sentence in which the maximum term was fixed at the time of commitment and the minimum term was some fraction thereof or a prescribed number of years dictated by a general provision of the penal law relating to parole eligibility. This differed from the indeterminate sentence primarily in that under the latter, both the minimum and the maximum terms are expressed in the sentence of the court within a range prescribed by law.

Today, there are eleven jurisdictions that employ this much modified, but stillcalled, definite sentence almost exclusively and eight others that use it preponderantly. Good-time laws, too, have been enacted in all states save California. Accordingly, except for the unusual case where a crime may require the imposition of a mandatory term without privilege of parole, the offender convicted of a felony and sentenced to a "fixed term" in fact faces an indefinite period of imprisonment, with a possibility of parole or early release on good time within that term.

The indeterminate sentence originally meant a term without a maximum or minimum length. It was in this sense that $Z$. R. Brockway and other penological idealists of the late nineteenth century used the term in their agitation for a sentencing system aimed at protecting society by controlling the offender for a period of unlimited duration. ${ }^{3}$ The view that offenders should be imprisoned until reformed appears to have derived largely from Italian positivistic criminology of this period. The influences of legalism and realism were powerful enough, however, to prevent the enactment of this form of indeterminate sentencing. Concern for personal liberty, skepticism concerning administrative decisions about prisoner reformation and readiness for release, insistence upon the preservation of some measure of deterrent emphasis, and other such factors, undoubtedly, led, instead, to a systemindeed, a complex of systems-in which maximum terms were generally employed.

At the Elmira Reformatory, where the relatively indeterminate-sentence system was first established, this involved a term not greater than that prescribed by the penal law for the crime involved; but release could occur whenever the offender was believed to have reformed. As sentences of indefinite duration came to be imposed upon adult felons, minimum as well as maximum terms were generally employed. And eventually, the indeterminate concept was translated into a variety of sentencing and release practices that bore no real resemblance to the principle of complete indeterminacy that had earlier been espoused by the criminological positivists. In fact, as will be seen, the indeterminate sentence has come to mean quite different

24 U.S. Dep't of Justice, Attorney General's Survey of Release Procedures 20 (1939).

${ }^{3}$ Z. R. Brockway, Fifty YeArs of Prison Service i 26 (IgI2). 
things in the several jurisdictions. One of the anomalies of sentencing law and practice is, however, that in many jurisdictions where this system has been adopted, the sentencing judge may, if he chooses, set the minimum and maximum terms so closely together that the result approximates that of the old, now obsolete, definitesentence systems; and, thus, if he so desires, he may make parole impossible.

Today, the partially-indeterminate sentence-in which the minimum and maximum terms are fixed by some agency within statutory limits-is employed in committing felons in a majority of jurisdictions. It is used exclusively-except for life-imprisonment terms and death sentences-in eight jurisdictions and preponderantly in an additional twenty-two. In 1950, thirty-eight states and the District of Columbia provided for the imposition of indeterminate sentences in some cases, and such sentences were actually employed in 57.6 per cent of prison terms in $1950,{ }^{4}$ as compared to 46.6 per cent in 1940.5

Analysis of the relevant statutes in the penal codes of the several jurisdictions points up the wide diversity of law and practice in the sentencing process. Table one indicates the major locus of sentencing power both in those jurisdictions that employ preponderantly the indeterminate sentence and in those in which the so-called definite sentence is mainly used. But the table reveals the variations only partially, for in some jurisdictions, definite, partially-indeterminate, and fully-indeterminate sentences are all used. In effect, however, these sentences tend to devolve into some indeterminate form whose upper and lower limits are set by law, court, or administrative agency. It will be noted that in a few jurisdictions, the statutes themselves indicate precisely the sentence which the court must impose; elsewhere, statutory limits are prescribed, but the specific terms of the sentence are determined by the judge, the jury, or an administrative agency in accordance with the legal provisions of the particular jurisdiction. In the definite-sentence jurisdictions, the minimum term is ordinarily determined by a general provision of the penal law, as has been remarked; in a few jurisdictions, however, no minimum term at all is prescribed, and the parole board is, therefore, empowered to release at any time.

The introduction of the indeterminate sentence and parole has had important consequences in practices of prison-sentencing and retention. One has been the considerable diversification of sentencing methods, apparent from table one. Another has been the establishment in certain jurisdictions of what seem unnecessarily high permissible terms, even if they are designed to constrain repetitive offenders. This may, perhaps, be interpreted as the persistence of an idealistic and largely anachronistic theory of unlimited control that was implicit in the completely indeterminate sentence principle. More likely, however, a single massive prison

- U.S. Bureau of Prisons, Dep't of Justice, Prisoners in State and Federai Institutions, i950, table 27 (1954).

s.S. Bureau of the Census, Dep't of Commerce, Prisoners in State and Federal Prisons and Reforaratories, I940, table I8 (I943).

- This table and an analysis of its implications appears in Model PeNal Code 26 et seq. (Discussion Draft No. 2, 1953). 


\section{TABLE I}

Authority for Setting Sentences

Indeterminate Sentences

Fixed by Statute:

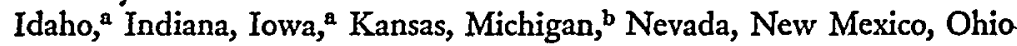

Fixed by Judge within Statutory Limits:

Arizona, Colorado, Connecticut, Illinois, Maine, Massachusetts, Michigan, Minnesota, ${ }^{a}$ New

Hampshire, New Jersey, New York, North Carolina, North Dakota, Oregon, ${ }^{a}$ Pennsylvania, Utah, ${ }^{c}$ Vermont, Wisconsin, Wyoming, District of Columbia

Fixed by Jury within Statutory Limits:

Georgia

Fixed by Administrative Agency within Statutory Limits:

California, Washington, West Virginia

\section{Definite Sentences}

Fixed by Statute:

Mississippi

Fixed by Judge within Statutory Limits:

Delaware, Florida, Louisiana, Maryland, Montana, Nebraska, Rhode Island, South Carolina, ${ }^{c}$ Féderal

Fixed by Jury within Statutory Limits:

Alabama, Arkansas, Kentucky, Missouri,c Oklahoma, ${ }^{c}$ Tennessee, Texas, Virginia

Fixed by Administrative Agency within Statutory Limits:

South Dakota

a No minimum term is fixed in these jurisdictions. In addition, there are nine others (Connecticut, Indiana, Kansas, Maine, Maryland, New Jersey, Ohio, Pennsylvania, and Wisconsin) where no minimum term is fixed for reformatory prisoners.

'In this jurisdiction, the minimum term is set by the court, while the maximum term is fixed by law.

' The parole board is empowered to release at any time in these jurisdictions.

a In this jurisdiction, the minimum term is fixed by law, while the maximum term is set by the court.

sentence is rather designed to incorporate not only a period of imprisonmentperhaps a long one-but also a period of parole supervision and, if necessary, a further reimprisonment for violation, perhaps with reparole. Such provisions for very high sentences have been especially characteristic in a few jurisdictions where the volume of crime is large. Furthermore, offenders can be retained in prison until the end of their maximum terms under these high sentences, since it has been held that parole is a matter of grace and may be withheld or revoked at the unfettered discretion of the authorities. Thus, individuals in these jurisdictions are subject to the possibility, and often to the fact, of greatly extended imprisonment. ${ }^{7}$ Elsewhere, much lower sentences are imposed for similar crimes. ${ }^{8}$ Indeterminate sentences-

${ }^{\top}$ See Modei. Penal Code rr4-24 (Tent. Draft No. 5, 1956).

${ }^{8}$ See U.S. Bureau of Prisons, Dep't of Justice, Prisoners Released from State and Frderal Institurions, x95r, table 5 ( 1955 ), in which the differences in duration of imprisonment for each of the major felonies is given according to jurisdiction. The median duration of imprisonment for robbery 
and, for that matter, definite sentences, too-accordingly, can be quite abusive in effect.

Another significant consequence of the introduction of parole has been a redistribution of powers relating to sentence and correction. Duration of imprisonment is determined not by statute or court alone, but, to a great and-as the institution of parole has evolved-an increasing extent, by the paroling authority. Within the range of the court's sentence, administrative discretion has become controllingpatently, a large power where the range of sentences is wide. This has been justified on the ground that the determination of the time when the offender is ready for release can better be made on the basis of his response to treatment and his plans for freedom than it could at the time of sentencing. The validity of this position is incontrovertible. What has not so commonly been recognized, perhaps, is the fact that where sentence lengths are great and parole board discretion is unlimited, the result may be unreasonably protracted imprisonment. Effective sentencing and parole policy, therefore, requires a nicely-balanced distribution of authority between the legislature, the courts, and the paroling agency, in which terms are high enough, but not excessive, and the paroling authority is soundly guided in the discharge of its function.

Contemporary appraisals of sentencing and correction practices reveal that the current methods of distributing power are something less than completely felicitous. Two general criticisms are common, the most frequent, perhaps, being that disparity of sentences exists not only from one jurisdiction to another, but within any jurisdiction from one offender to another similar offender. While the virtues of individualization of treatment are generally acknowledged, there is a strong suspicion that the prevailing variations are quite arbitrary, reflecting differences between statutes, individual judges, and parole commissioners more largely than those between the offenders with whom they deal. Criticism is also directed against the excessive length and differences in duration of imprisonment.

As has been suggested above, the problems involved in sentencing and release practices are too subtle relative to the present state of criminological knowledge and opinion to permit arrival at firm and simple solutions. Even the basic objectives of correction raise dispute among reputable authorities: What ends should be sought through the sentencing and treatment of different types of offenders? To what extent is it feasible to attain them by the measures that are available? Relative to the personality of the offender, the seriousness of his crime and his threat to the community, and society's need for deterrence, how should he be sentenced and how long incarcerated?

The contrariety of expert opinion about sentencing procedures and their effects is well illustrated by the views lately expressed by the National Probation and Parole

ranged from ten months in Maine to seventy-five months in Indiana. For aggravated assault, the range was from eight months in Colorado to forty-five months in Illinois. For all offenses, the lowest median was nine months in Vermont; the highest, thirty-five months in Illinois. 
Association, an organization that has taken considerable interest in these matters. The 1955 draft of the Association's Standard Probation and Parole Act provided that maximum terms of prison sentences should be fixed by law rather than by the courts and that the court should have the discretionary power to impose either a minimum term up to one-third of the statutory maximum term or no minimum term at all. ${ }^{9}$ In a statement endorsed by the Association's Advisory Council of Judges in 1956 opposing the sentencing provisions of the Model Penal Code of the American Law Institute, however, this group took the view, quite opposed to the Standard Act, that the judge should be empowered to fix the maximum term and that there should be no minimum term. ${ }^{10}$ This position was rationalized on the ground that where maximum terms are prescribed by law, they tend to be too high and that the length of imprisonment is directly related to the length of maximum terms. Attention will be given to this view below. Also in 1956, the Assistant Director of the Association in an article on sentencing in its official journal, took a position different from either of these, proposing "a uniform provision under which the courts would commit for the statutory maximum [a term prescribed in the article as fifteen years, apparently without regard to the offense] without a minimum."11 And in the same issue, the legal counsel of the Association expressed a policy view differing from all the diverse ideas reflected in the Association, submitting that there should be return to a system of definite sentencing. ${ }^{12}$ He argued here, as is done elsewhere in the literature, that imprisonment is shorter where definite sentences are used and that legislation should focus primarily on the goal of reducing the length of commitments.

The relationship of the length of imprisonment to the length of sentences is a matter of great importance, of course, about which more should be known than can be gleaned from a superficial inspection of the mass data collected by the various jurisdictions. Unfortunately, too easy inferences have been drawn from the available material, sometimes conclusions that are quite misleading. ${ }^{13}$ It may be useful to scrutinize some of these data, with a view to more accurate appraisal of their significance.

- NPPA, Standard Probation and Parole Act $\$$ I2 (1955). Commentary on this section revealed a widespread divergence of views among the committee members who participated as to whether there should be a minimum term and whether the limits of the sentence should be fixed by the judge or by law.

${ }^{10}$ See Ali, Model Penal Code, Memorandum for Advisory Commitiez app. B, at 5-8 (I957).

${ }^{11}$ Rector, Sentencing and Corrections, 2 N.P.P.A.J. 352, $357-58$ (1956).

${ }^{12}$ Rubin, Long Prison Terms and the Form of Sentence, 2 id. at 337 (1956). Rector said: "I do not agree with Mr. Rubin in his conclusion that the indeterminate form of sentencing is less compatible with modern correctional philosophy than is the definite sentence and that it should be abolished. The similarity in practice between the two forms shows clearly that the principle of the indeterminate sentence is sound and that the solution to our difficulty is in further improving the use of the indeterminate form of sentence by the courts and parole authorities rather than in abandoning it." Rector, supra note II, at 355 .

13 "... behind the relatively simple statistical data for each State, and among States, lies an intricate, complex webbing of criminal codes, sentencing practices, and parole laws and policies, extremely difficult to unravel." U.S. Bureat of Prisons, Dep't of Justice, Prisoners Released frox State and Federal INstTtutions, I95I, at 8 (1955). 
In table two appear the figures most recently published by the Federal Bureau of Prisons on what seems to be a reasonably representative variety of jurisdictions employing definite sentences; indeterminate sentences in which the maximum term is fixed by statute, including two jurisdictions where a paroling authority determines the time of release and discharge; and indeterminate sentences in which the maximum term is fixed by the court. The table offers data on the lengths of prison terms being served in 1950, including not only detailed figures on the seventeen jurisdictions listed, but also summary figures for all definite and indeterminate sentences being served that year. The table also provides general data on the length of imprisonment before the first release of offenders discharged in I95I and percentage figures for the cases in which discharge was on parole. It is believed that a number of propositions may be drawn from this material:

Definite sentences imposed by courts in the United States are of shorter duration, of course, than the maximum limits of indeterminate sentences: only thirty-two per cent of the definite sentences were in excess of five years, as compared to sixty-seven per cent of indeterminate sentences. This contrast reflects the different policy base of the definite-sentence system. Shorter average duration of imprisonment is also characteristic under definite sentences, although the difference is not great: a median of twenty months, as compared to a median of twenty-four months under indeterminate sentences. The difference can be accounted for, in considerable part, however, by the greater proportion of offenders in the indeterminate-sentence jurisdictions who are retained in excess of five years, particularly in certain crucial jurisdictions.

Closer analysis reveals that thirteen of the fifteen southern jurisdictions of the United States use definite sentences primarily. Only five other, relatively nonpopulous and noncriminal, jurisdictions are similarly committed to definite sentences. Clearly, it is characteristic of the southern states to use low sentences and to imprison offenders for relatively brief periods. That shorter incarceration should be attributed to the employment of definite sentences itself, however, does not necessarily follow. Undoubtedly, a factor of major importance is the relatively more limited use of probation in the southern jurisdictions, so that "good cases" more commonly are imprisoned for short terms and are held only briefly. Furthermore, the data on certain of these southern jurisdictions-e.g., Florida and Louisiana-reveal that where crime is deemed a serious problem, the authorities are reluctant neither to employ high terms in a considerable number of cases nor to retain such offenders for extended periods in prison. It should be observed further that in several of the definitesentence jurisdictions, a relatively large proportion of minor offenders are held in high-term penal institutions, their early release affecting the median imprisonment data to some extent. ${ }^{14}$ Finally, it may be noted that those jurisdictions that use primarily indeterminate sentences, in those cases in which they do employ definite

\footnotetext{
26 The Federal Bureau of Prisons observes that this is particularly characteristic in Maryland, Delaware, and Rhode Island. Id. at 7 .
} 
TABLE II

Sentence Lengths and Time Served ${ }^{a}$

\begin{tabular}{|c|c|c|c|c|c|c|c|c|c|c|c|c|}
\hline & \multicolumn{8}{|c|}{$\begin{array}{c}\text { Sentence Irngths: Definite Sentences and Maximum Terms of Indefinite } \\
\text { Sentences, } 1950\end{array}$} & \multicolumn{3}{|c|}{$\begin{array}{l}\text { Timo Served beforo First } \\
\text { Release, } 1051\end{array}$} & \multirow{2}{*}{$\begin{array}{c}\text { Per- } \\
\text { centago } \\
\text { Released } \\
\text { on } \\
\text { Parolo }\end{array}$} \\
\hline & $\mid \begin{array}{c}6 \text { months } \\
\text { to } 2 \\
\text { years }\end{array}$ & $\begin{array}{l}2 \text { to } 4 \\
\text { years }\end{array}$ & $\begin{array}{l}5 \text { to } 9 \\
\text { years }\end{array}$ & $\begin{array}{l}10 \text { to } 19 \\
\text { years }\end{array}$ & $\begin{array}{l}20 \text { to } 99 \\
\text { years }\end{array}$ & Life & $\begin{array}{l}\text { Indef- } \\
\text { inite }\end{array}$ & Total & $\mid \begin{array}{c}\text { Median } \\
\text { (months) }\end{array}$ & $\begin{array}{c}\text { Middile } \\
80 \mathrm{per} \\
\text { cent } \\
\text { (months) }\end{array}$ & $\begin{array}{c}\text { Per- } \\
\text { centago } \\
\text { over b } \\
\text { years }\end{array}$ & \\
\hline $\begin{array}{l}\text { Definife Sentences } \\
\text { Montana......... } \\
\text { Nebraska........ } \\
\text { Florida........... } \\
\text { Louisiana........ } \\
\text { Missouri......... } \\
\text { All definite } \\
\text { sentences......... }\end{array}$ & $\begin{array}{r}192 \\
184 \\
315 \\
246 \\
0 \\
4942\end{array}$ & $\begin{array}{r}144 \\
148 \\
632 \\
474 \\
1163 \\
8648\end{array}$ & $\begin{array}{r}51 \\
48 \\
343 \\
269 \\
258 \\
\\
3114\end{array}$ & $\begin{array}{r}18 \\
13 \\
122 \\
103 \\
80 \\
\\
1591\end{array}$ & $\begin{array}{r}3 \\
7 \\
68 \\
25 \\
24 \\
\\
588\end{array}$ & $\begin{array}{r}1 \\
3 \\
28 \\
40 \\
18 \\
\\
768\end{array}$ & & $\begin{array}{r}403 \\
403 \\
1515 \\
1157 \\
1643 \\
\\
19728\end{array}$ & $\begin{array}{l}12 \\
18 \\
23 \\
17 \\
16 \\
\\
\\
\end{array}$ & $\begin{array}{r}6-30 \\
0-30 \\
10-54 \\
6-61 \\
10-40 \\
8-57\end{array}$ & $\begin{array}{r}1.0 \\
2.7 \\
7.5 \\
10.5 \\
0.5\end{array}$ & $\begin{array}{l}49.5 \\
18.1 \\
30.7 \\
62.4 \\
27.8\end{array}$ \\
\hline $\begin{array}{l}\text { Indeterminate } \\
\text { Sentences } \\
\text { Mfarimum fixed by } \\
\text { Statute } \\
\text { Nevada......... } \\
\text { Iora............ } \\
\text { Kansas.......... } \\
\text { Indiama......... } \\
\text { Ohio............. }\end{array}$ & $\begin{array}{r}0 \\
46 \\
8 \\
0 \\
3\end{array}$ & $\begin{array}{r}8 \\
17 \\
33 \\
14 \\
287\end{array}$ & $\begin{array}{r}34 \\
100 \\
323 \\
378 \\
364\end{array}$ & $\begin{array}{l}119 \\
104 \\
344 \\
549 \\
674\end{array}$ & $\begin{array}{r}2 \\
9 \\
73 \\
101 \\
1207\end{array}$ & $\begin{array}{l}4 \\
1 \\
1 \\
0 \\
4\end{array}$ & $\begin{array}{r}0 \\
3 \\
0 \\
22 \\
0\end{array}$ & $\begin{array}{r}167 \\
280 \\
782 \\
1064 \\
2539\end{array}$ & $\begin{array}{l}10 \\
24 \\
16 \\
24 \\
24\end{array}$ & $\begin{array}{r}10-22 \\
0-57 \\
10-43 \\
12-57 \\
10-57\end{array}$ & $\begin{array}{l}2.0 \\
5.8 \\
7.1 \\
0.0 \\
8.7\end{array}$ & $\begin{array}{l}06.0 \\
41.0 \\
85.3 \\
80.3 \\
03.2\end{array}$ \\
\hline $\begin{array}{l}\text { Washingtonb..... } \\
\text { Calfforniab...... }\end{array}$ & $\begin{array}{l}0 \\
2\end{array}$ & $\begin{array}{r}1 \\
15\end{array}$ & $\begin{array}{r}20 \\
442\end{array}$ & $\begin{array}{r}582 \\
1749\end{array}$ & $\begin{array}{l}305 \\
162\end{array}$ & $\begin{array}{r}11 \\
683\end{array}$ & $\begin{array}{l}6 \\
1\end{array}$ & $\begin{array}{r}025 \\
3054\end{array}$ & $\begin{array}{l}17 \\
30\end{array}$ & $\begin{array}{r}8-62 \\
18-56\end{array}$ & $\begin{array}{r}13.7 \\
8.7\end{array}$ & 100. \\
\hline $\begin{array}{l}\text { Indeterminate } \\
\text { Sentences- } \\
\text { Maximum fixed by } \\
\text { Count } \\
\text { Minnesota........ } \\
\text { Illinois........... } \\
\text { Pennsylwanis..... } \\
\text { New York........ } \\
\text { New Jersey...... } \\
\text { All indeterminate } \\
\text { sentences......... }\end{array}$ & $\begin{array}{r}28 \\
107 \\
12 \\
6 \\
39 \\
\\
1524\end{array}$ & $\begin{array}{r}80 \\
622 \\
293 \\
770 \\
552 \\
6214\end{array}$ & $\begin{array}{r}324 \\
519 \\
405 \\
1211 \\
489 \\
\\
7517\end{array}$ & $\begin{array}{r}148 \\
347 \\
319 \\
588 \\
175 \\
\\
7496\end{array}$ & $\begin{array}{r}76 \\
71 \\
231 \\
162 \\
27 \\
\\
2857\end{array}$ & $\begin{array}{r}5 \\
24 \\
1 \\
66 \\
0 \\
865\end{array}$ & $\begin{array}{r}0 \\
5 \\
135 \\
70 \\
46 \\
\\
295\end{array}$ & $\begin{array}{r}601 \\
1625 \\
1396 \\
2873 \\
1328 \\
\\
26768\end{array}$ & $\begin{array}{l}25 \\
35 \\
31 \\
31 \\
20 \\
\\
24\end{array}$ & $\begin{array}{l}13-47 \\
12-102 \\
16-84 \\
15-56 \\
10-57 \\
10-50\end{array}$ & $\begin{array}{r}5.7 \\
20.3 \\
21.7 \\
17.0 \\
8.7\end{array}$ & $\begin{array}{l}74.3 \\
47.1 \\
80.1 \\
76.7 \\
78.0\end{array}$ \\
\hline All States. & & & & & & & & & 21 & $9-81$ & 10.1 & 65.8 \\
\hline
\end{tabular}

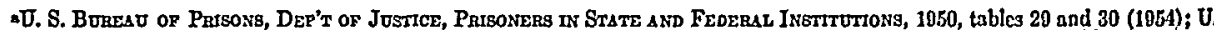

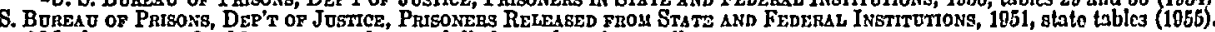

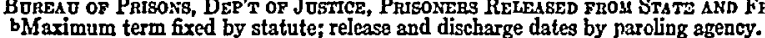

sentences, impose similarly high terms on such prisoners. ${ }^{15}$ Definite sentences and the retention of definite-sentence prisoners, accordingly, are not necessarily brief.

Indeterminate sentences are employed for the majority of prison commitments, it will have been noted in table one, in nearly all of the jurisdictions that are progressive in their correctional orientation-as well as in some that are not, of course. It is striking to observe from the federal data that six jurisdictions-California, Illinois, New Jersey, New York, Ohio, and Pennsylvania-are responsible for nearly thirty per cent of all prison commitments in the United States and for nearly onehalf of all indeterminate sentences. These are all indeterminate-sentence jurisdic-

${ }^{25}$ See U.S. Bureau of Prisons, Dep't of Justice, Prisoners in State and Federal Institutions, 1950, table 29 (1954)-particularly the definite terms imposed in Illinois, Indiana, Iowa, Kansas, Massachu-setts, Ohio, North Carolina, and West Virginia. 
tions; they are also populous and urban jurisdictions of the eastern and north-central regions (except for California), where the volume of crime is large and where public and official consciousness of the problem is acute. It is highly significant-although scarcely surprising-that these jurisdictions, especially California, Illinois, New York, and Pennsylvania, not only employ high sentences, but display the highest rates of median prison retention and the highest proportions of offenders retained over five years, as compared to the country as a whole. Obviously, they weigh very heavily, indeed, in the over-all data on lengths of sentence and of incarceration.

The national picture of sentencing and imprisonment is highly colored, then, by a dozen southern jurisdictions, where terms are low, on the one hand, and a halfdozen northern and eastern jurisdictions, on the other hand, where sentences are high, prison populations large, and a large proportion of offenders are retained for extended periods. It should be observed, too, that the duration of imprisonment in these latter jurisdictions is increased by two other factors that are in contrast with the South: Probation takes the best cases in these jurisdictions, where probation resources are relatively good, the more dangerous and recidivous offenders being imprisoned for high terms. Moreover, in several of these jurisdictions, many of the less serious felons are incarcerated in county and local institutions, so that state prison data indicate longer average and median retention than would be the case if all felons were covered. ${ }^{16}$

We come now to a comparison between indeterminate-sentence jurisdictions where the maximum terms are prescribed by statute and those where the maximum terms are fixed by the courts. It appears, again, that facile inferences about the relationship between the length of imprisonment and maximum sentences are quite inaccurate. Unfortunately, data for Michigan are not available, but for the other jurisdictions that employ statutorily-prescribed maximum terms, the maximum sentences are higher, as one should anticipate, than those where judges fix the terms. The data for I95I reveal, in fact, that where the maximum term was prescribed by law, ninety-one per cent of the sentences were for five years or more and sixty-six per cent for ten years or more. In those jurisdictions where the judges fixed the maximum term, however, only sixty-seven per cent of the sentences were for five years or more and forty-two per cent for ten years or more. Yet, it will be observed in table two, comparing the two categories of jurisdictions, that where the penal law prescribes the maximum terms, the median lengths of actual imprisonment are lower and the percentages of offenders actually serving in excess of five years are smaller than is true in the group of jurisdictions where the maximum terms are fixed by the courts. ${ }^{17}$ Neither the statutory determination of maximum terms nor higher maximum terms themselves, therefore, necessarily result in a longer duration

\footnotetext{
${ }^{20}$ The Federal Bureau of Prisons notes that this is true especially in New York, Ohio, and Pennsylvania. U.S. Bureau of Prisons, Dep't of Justice, Prisoners Released from State and Federas Institutions, 1951, at 7 (1955).

${ }_{17}$ The median period of imprisonment is over twenty-four months also in Massachusetts, North Carolina, and West Virginia, other jurisdictions where the court fixes the maximum term.
} 
of imprisonment. This is not to deny, of course, that the jurisdictions which employ statutory maximum terms differ from those where maximum terms are fixed by the courts or from those where definite sentences are used. On the contrary, it should be emphasized that length of imprisonment is related to local and regional characteristics of crime and public opinion, rather than merely to the type of sentencing system or to the length of terms imposed by the courts.

It should also be observed that in each of the jurisdictions, except Iowa and California, where statutory maximum terms are employed, eighty per cent or more of released offenders in I95I were discharged by parole. ${ }^{18}$ This may be compared to 55.9 per cent of parole discharges for the country as a whole. Among definitesentence jurisdictions, only Arkansas exceeded this average, and only Louisiana and Montana came close to it; half of the definite-sentence states discharged fewer than thirty per cent of their prisoners on parole. This points up the fact that in these jurisdictions, definite terms are still looked upon as the length of time that prisoners are expected to serve, and offenders are released generally without the advantage of planning, guidance, or control. In the indeterminate-sentence jurisdictions, on the other hand, particularly in those where statutory maximum terms are employed, parole is looked upon as a normal consequence of imprisonment.

\section{III}

The American Law Institute has given critical attention to the problems of sentencing and treatment, seeking to arrive, in its Model Penal Code, at a policy that might achieve the legitimate ends of correction with increasing effectiveness. Among other issues, special consideration has been devoted to the problems raised in this paper. The result has been the formulation of certain tentative policy conclusions and draft provisions that are set forth summarily below. It is not possible within the limitations of space available here fully to detail the reasoning on which these have been based, but the following general proposals have been made relative to prison terms and parole. ${ }^{19}$

\section{A. Graded Felonies With Minimum and Maximum Terms}

Felonies are graded into three categories according to their seriousness, with sentences of indeterminate length for each category. The maximum terms for ordinary offenders would be uniformly prescribed by statute, while the minimum terms would be fixed by the court within a limited range established by law, ${ }^{20}$ as indicated in table three.

That prison sentences should be indeterminate in length appears entirely justifiable on the basis of experience and reason. How long the offender should be imprisoned

\footnotetext{
${ }^{19}$ U.S. Bureau of Prisons, Dep't of Justice, Prisoners in State and Federal Institutions, 1950, chart 6 (I954), based on releases in 195I.

${ }_{10}$ For more extensive treatment, see especially MOdel PeNar Code $\$ \$ 6.01,6.06$ (Tent. Draft No. 2, 1904); $\$ 6.09 A, 305.10,305.12,305.13,305.22$, and commentary thereon (Tent. Draft. No. 5, 1956).

${ }^{20} I d$. $\$ 6.05(2)$ (Tent. Draft No. 7, I957) provides for a term without a minimum applicable at the diseretion of the court to young adult offenders.
} 
TABLE III

Ordinary Terms for Felons

\begin{tabular}{lll} 
Grade of Felony & \multicolumn{1}{c}{ Minimum } & \multicolumn{1}{c}{ Maximum } \\
(fixed by court) & (fixed by law) \\
first degree & one to ten years & life imprisonment \\
second degree & one to three years & ten years \\
third degree & one to two years & five years
\end{tabular}

cannot be precisely determined in advance, but should be related to his behavior and attitude in the correctional situation. Furthermore, the range between minimum and maximum terms should be sufficiently wide to adjust the treatment period to the

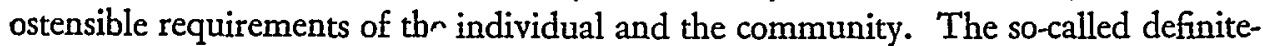
sentence system, as noted above, could provide a range of term through establishing the minimum term at some fraction of the sentence. But this is an artificial and awkward, not to say mechanical, means by which to achieve indeterminacy. It would, moreover, tie the duration of minimum and maximum terms rigidly together, so that no adjustment could be made in the former without alteration of the latter. The only major argument, in fact, that has been adduced for this obsolescent form of sentence is that definite terms result in shorter incarceration. As we have seen, however, it is badly simplistic reasoning to infer that such a result proceeds automatically from a system of definite sentencing as such. The spread between minimum and maximum terms should be determined, instead, by considerations appropriate to each, rather than by an inflexible formula that controls one through the other.

The classification of felonies and graduated sanctions into three categories is based upon the well-established principle that penalties should be gauged generally to the extent of the offender's threat to the community, so as to permit a sufficient length of treatment and custody. This gradation of indeterminate sentences is believed to provide as discriminating a classification of the differences in the seriousness of crimes and in the requirements for long-term treatment as can be justified at the time of sentencing. Such a set of categories would, moreover, provide a simplicity of system that should contrast remarkably with the diversity of limits that has developed ad hoc in our prevailing penal law. It would avoid the invidious variations in terms that are imposed upon offenders of similar sort and remove, thereby, a substantial basis for the sense of injustice that erodes the spirit of many prisoners. The establishment of uniform maximum terms prescribed by statute at each level would go further still to eliminate the chaos of disparate sentences produced by the present law as it is administered by judges whose value systems differ markedly. Courts would still, however, retain wide powers to determine sentences by selecting between fine, probation, and imprisonment; by reducing the grade of crime where appropriate; by choosing between ordinary and extended terms; ${ }^{21}$ and in fixing the minimum term.

${ }^{21}$ The terms discussed in this paper are those applicable to the ordinary felon. The Code, however, also provides for extended terms that may be imposed, in the discretion of the court, upon "persistent 
The power to fix maximum terms, while it may be cherished by some courts, has proved too costly a restriction upon the legitimate province of correctional administration. Along with the wide disparity in sentences it conduces, judiciallydetermined maximum terms have afforded poor guidance to parole decisions-some prisoners being held too briefly because the court-imposed maximum term either required or appeared to suggest brief retention; others, too long because of the persuasive power implicit in extreme terms that have been fixed by a judge. Hence, it has been concluded that professionalized parole authorities should be entrusted with the discretion to limit or extend imprisonment within the range of flexibility provided by reasonable maximum terms established in the law.

As to the duration of maximum terms, it is clear that, while these should be sufficiently high to provide adequate social safeguard, they should not encourage abusive prison retention and hopelessness among prisoners. A determination as to the optimal length of prison terms is necessarily based, in part, upon arbitrary judgments which, as present penal law makes obvious, vary greatly in different times and places. The Code proposals do, however, reflect a careful appraisal of present sentencing in the United States and of the periods of imprisonment that eventuate under the sentences imposed. It is believed that the common use of life imprisonment-terms, terms of twenty, twenty-five, and fifty years, and of very high consecutive terms is unnecessary and undesirable, the more especially where nonviolent felonies are involved. ${ }^{22}$ They produce desperation in prisoners, without sufficient compensating gains in deterrence, so far as one can discover. The Code maximum terms for such felonies are lower than those prevailing in a number of the jurisdictions that employ an indeterminate-sentence system; yet, they should afford sufficient protection proportioned to the seriousness of the crimes involved. Furthermore, the Code looks toward release to parole when it appears that the offender may safely be discharged from prison. Thus, the thrust is toward early release of

offender[s]," "professional criminal[s]," "dangerous, mentally abnormal person[s]," and "multiple offender[s]," as defined in id. $\$ 7.03$ (Tent. Draft No. 2, 1954), when it is believed that such terms are necessary for the protection of the public. But the court must find specified circumstances to exist in order to impose the extended terms. It appears that a wider judicial discretion is required in fixing the length of such terms, and the judge is given authority to set both minimum and maximum terms within these ranges:

\begin{tabular}{lll} 
Grade of Felony & Minimum & \multicolumn{1}{c}{ Maximum } \\
first degree & ten to twenty years & life imprisonment \\
second degree & one to five years & ten to twenty years \\
third degree & one to three years & five to ten years
\end{tabular}

${ }^{22}$ Each of the six jurisdictions referred to in the text above provide by statute for maximum terms of twenty years to life imprisonment for a large number of felonies. In Illinois, 126 crimes are punishable by terms of ten years or more, 34 by terms of twenty years or more. In California, the comparable figures are 83 and 2r. Maximum terms of ten years or more were imposed in 84.9 per cent of prison sentences in California in 1950, 74.2 per cent in Ohio, 63.2 per cent in Indiana, 49.1 per cent in Pennsylvania, 30.8 per cent in New York, 26.4 per cent in Illinois, and 18.6 per cent in New Jersey. Also, high consecutive terms are commonly assessed by the courts, a practice that would be carcfully controlled under $i d$. $\$ 7.06$. 
those who do not offer a substantial threat of violation. ${ }^{23}$ On the other hand, an offender could be held for a long period, either when his crime was violent or when his criminal history or personality appeared to justify the use of an extended term. ${ }^{24}$

Minimum terms under the Code would be fixed by the judge within statutory ranges which, except for felonies of the first grade, are rather low. The matter of minimum terms, their use and length, is controversial, owing, in part, to the clash of positivistic theory, on the one hand, and demands of social defense, on the other. In most jurisdictions, however, as has been seen, minimum terms have been deemed a matter of practical expedience. Thus, even where they are not established by law, they are commonly applied, in fact, by administrative practice. It is believed that minimum terms should be employed for adult offenders in the interest of general and individual prevention. They should be low enough to provide reformative incentive, and in many cases, they need be no higher than is required for the prison's program of classification, brief treatment, and parole preparation. This can be accomplished in something less than a year ordinarily-a one-year minimum term, less good-time earnings. In other cases, however, it is quite clear at the time of sentence from the offender's record and character that a higher minimum term should be fixed, both to assure a sufficient period of treatment and as a matter of general deterrence. The court itself should have power to set much higher minimum terms, for it is at the time of sentence that the gravity of the crime is publicly assessed and prevention receives its proper emphasis. But for less serious offenses, such minimum terms need not be high. It is only in the case of violent felonies, therefore, that the Code provides a considerable latitude in the setting of the minimum.

\section{B. Separate Mandatory Parole Term}

A "parole term," distinct from the term of imprisonment, is introduced as a part of the sentence of the court, and parole planning and supervision is employed

${ }^{23}$ Id. $\$ 305.13$ (Tent. Draft. No. 5, 1956) provides a series of criteria for determining date of release on parole:

"(x) Whenever the Board of Parole considers the release of a prisoner who is eligible for release on parole, it shall order his release, unless the Board is of the opinion that his release should be deferred because:

(a) there is substantial risk that he will not conform to the conditions of parole; or

(b) his release at that time would depreciate the seriousness of his crime or promote disrespect for law; or

(c) his release would have a substantially adverse effect on prison discipline; or

(d) his continued correctional treatment, medical care or vocational or other training in the institution will substantially enhance his capacity to lead a law-abiding life when released at a later date." The section provides that the certain specified considerations and data should be taken into account in arriving at the release decision.

At a number of other points in the Code, criteria have been formulated to guide decision-e.g., in the sentencing provisions. See id. $\$ \$$ 7.0r-7.05 (Tent. Draft No. 7, 1957). On the value of articulating criteria in the penal law, Professor Wechsler, Chief Reporter on the project, has said: ". . . the development of statutory norms, mediating soundly between rule and discretion, represents one of the greatest long-range needs of the entire field. The lack of such norms and of attention to the ways in which they might be formulated may well be one of the important reasons why legislative participation in this field, when it comes, so often is harsh and unsatisfactory."

${ }^{2}$ See note 21 supra. 
in all cases released from prison. These represent two significant departures in sentencing and treatment practice. The Code will avoid the anomaly inherent in present laws in which parole is carved out of the prison sentence, whereunder "good" offenders are released early to face long supervision, "bad" ones retained throughout most or all of their terms to be released with little or no supervision. Under the Code proposal, when the parole authority released the prisoner for the first time, this would terminate the prison term assessed by the court. Every offender would then be submitted to an indefinite parole term, with a maximum duration of five years, a term from which he could be discharged earlier by the board. ${ }^{25}$ Before such discharge, however, he might be returned to prison to serve a portion of the parole term if his parole was revoked for violation.

It is contemplated that most circumstantial and first offenders who displayed no serious abnormality or aggression related to their crimes and who responded well to treatment would be released early from prison and, under similarly favorable circumstances, discharged early from parole. Dangerous and repetitive offenders could be held long enough to assure community protection and would be subject to control and reimprisonment if necessary, even after the specifically institutional phase of the sentence had been terminated. In many jurisdictions, the effect of this should be to abbreviate imprisonment of a considerable proportion of offenders, as has previously been suggested, while a minority of more dangerous and recalcitrant criminals would be subject to longer control than they are today in some-especially southern and New England-jurisdictions.

It may be clear that the orientation of the Code provisions for the handling of release and parole differs from that of the traditional pattern under which many prisoners are retained in prison by reason of the fear of parole boards that they might violate parole. This anxiety is understandable under existing parole systems that measure board achievement by violation rates. Boards assume no responsibility for the consequence where offenders are discharged by operation of law without supervision, whereas they are expected to make few "mistakes" in releasing individuals on parole who may offend while under supervision. Under the American Law Institute plan, however, parole boards would face a different issue than they do now: The question would be when rather than if the offender should be released on parole. Over-all parole violation rates might very possibly be higher, since some men would be paroled who today are discharged at the end of their terms without supervision. Yet, if parole has any virtue as a form of correctional case work in contributing to the conformity of released prisoners, fewer of these difficult offenders would recidivate. It is surely the major objective of correction, parole included, to reduce the total rates of recidivism rather than merely that of "good" cases. More-

${ }^{25}$ Moder Penal Code $\$ 6.09$ A (Tent. Draft. No. 5, 1956) provides that: "An offender sentenced to an indefinite term of imprisonment in excess of one year ... shall be released conditionally on parole at or before the expiration of his maximum sentence. ..." Relative to discharge from parole, $i d$. $\$ 305.15$ provides: "A parolee is eligible for discharge from parole upon the satisfactory completion of his minimum parole term less reductions for good behavior. . . ." 
over, the performance of the average offender should improve under a system in which sound criteria guide the determination of parole release.

\section{IV}

In light of the diversity of law and practice that has been noted and the disparity of views that have been expressed, the complexity of the issues that are involved in sentencing and parole should readily be appreciated. While there is widespread dissatisfaction with prevaling legislation and administration, there is little inclination among authorties either to agree on solutions or to look favorably upon innovations. The Code proposals will be controversial, therefore, but it is hoped that they may play some significant role in our common efforts to achieve the multiple ends of correction more effectively. Critical evaluations of the Code drafts by interested persons will be welcomed by the Code Reporters. 